\title{
Assessment of final year medical students knowledge of basic head and neck clinical anatomy
}

\author{
J Al Amiri ${ }^{*}$, MA Walsh ${ }^{2}$ \\ From International Conference for Healthcare and Medical Students (ICHAMS) 2013 \\ Dublin, Ireland. 11-12 October 2013
}

\section{Background}

At the Royal College of Surgeons in Ireland (RCSI) anatomy teaching is carried out during the preclinical years by using various modalities to maximize students learning. The purpose of this study is to assess how much did final year student retain from the basic clinical anatomy of the head and neck and to determine if reinforcement of anatomy is required throughout the medical school curriculum.

\section{Methods}

The study was carried out on 247 final year RCSI medical students. The students were asked to complete a multiple-choice quiz within 12 minutes. In addition, they were invited to fill in a short survey regarding their opinion on the anatomy curriculum.

\section{Results}

The response rate to the quiz and survey were $64.78 \%$ and $55.56 \%$, respectively. Out of a maximum score of 15 , the mean score achieved was 7.58 and the mode was 9. Using the mode as our acceptable standard; $41.25 \%$ of the class passed the quiz. Students scored highly on neck surface anatomy questions, while scored low on questions related to cranial and peripheral nerves; cervical vertebra; and scalp injury. The majority of the responders to the survey felt that anatomy taught in the preclinical years was clinical relevant and that it should be reinforced throughout the clinical years.

\section{Conclusions}

The knowledge of final year medical students of basic head and neck anatomy was acceptable, considering the time span between their preclinical and clinical years. However, the results highlight the need for reinforcement

\footnotetext{
${ }^{1}$ Royal College of Surgeons in Ireland, 123 St. Stephen's Green, Dublin 2, Ireland

Full list of author information is available at the end of the article
}

of relevant clinical anatomy throughout their clinical years of teaching.

\section{Authors' details}

${ }^{1}$ Royal College of Surgeons in Ireland, 123 St. Stephen's Green, Dublin 2, Ireland. ${ }^{2}$ Otolaryngology Head and Neck Surgery, Royal College of Surgeons in Ireland, Beaumont Hospital, Dublin 9, Ireland.

Published: 14 January 2015

doi:10.1186/1753-6561-9-S1-A58

Cite this article as: Al Amiri and Walsh: Assessment of final year medical students knowledge of basic head and neck clinical anatomy. BMC Proceedings 2015 9(Suppl 1):A58.
Submit your next manuscript to BioMed Central and take full advantage of:

- Convenient online submission

- Thorough peer review

- No space constraints or color figure charges

- Immediate publication on acceptance

- Inclusion in PubMed, CAS, Scopus and Google Scholar

- Research which is freely available for redistribution

\section{() Biomed Central}

